\title{
PERENCANAAN STRATEGIK PRODUK HORTIKULTURA DI AGRIBUSINESS DEVELOPMENT CENTRE IPB
}

\author{
Fadila Ramadini'), Endang Gumbira Sa'id $^{2)}$ dan Retnaningsih ${ }^{3)}$ \\ ${ }^{1,2,3)}$ Manajemen Bisnis, Institut Pertanian Bogor \\ ${ }^{1)}$ ramadini.05@gmail.com
}

\begin{abstract}
Agribusiness Development Center (ADC) is farmers support institution to produce and distribute top grade horticulture products. The purpose of this study is to formulate strategic planning for ADC. The methods used are internal and external factors analysis, IE matrix, SWOT and QSPM. The result shows five strategies prioritized as follows: expanding Greater Jakarta market, increasing organic products yield, collaborating with research institutes, increasing promotion and adding new distribution channels.
\end{abstract}

Keyword(s): horticulture products, QSPM, strategic planning, SWOT

\begin{abstract}
ABSTRAK
Agribusiness Development Center (ADC), adalah institusi pendamping petani untuk menghasilkan dan mendistribusikan produk hortikultura dengan mutu sangat baik. Tujuan dari penelitian ini memformulasikan perencanaan strategik ADC. Metode analisis yang digunakan adalah analisis faktor internal dan eksternal, matriks IE, SWOT, dan QSPM. Hasil penelitian menunjukkan lima strategi dengan prioritas sebagai berikut: memperluas pasar di Jabodetabek, meningkatkan hasil produk organik, bekerjasama dengan lembaga penelitian, meningkatkan promosi dan strategi menambah saluran distribusi baru.
\end{abstract}

Kata Kunci: SWOT, QSPM, perencanaan strategik, produk hortikultura.

\section{Latar Belakang}

\section{PENDAHULUAN}

Permintaan terhadap produk hortikultura terutama sayuran segar semakin meningkat berdasarkan data yang dipublikasi oleh Pusat Kajian Hortikultura Tropika (PKHT) (2013), tingkat konsumsi sayur dan buah penduduk Indonesia tahun 2005 sebesar 60,50 kg perkapita per tahun, tahun 2008 sebesar $71,38 \mathrm{~kg}$ per kapita per tahun dan tahun 2011 sebesar 145,44 kg per kapita per tahun. Jumlah tersebut masih dibawah standar yang disarankan oleh Organisasi Pangan Sedunia (FAO) yaitu sebesar 73 kg perkapita. Menurut Poerwanto (2008) tuntutan konsumen terhadap produk hortikultura semakin meningkat, baik dari segi mutu, kuantitas, nilai gizi, dan keamanan. Oleh karena itu produk hortikultura harus memenuhi syarat: (1) Aman, bebas dari cemaran, racun, pestisida, dan mikroba berbahaya bagi kesehatan. (2) Mempunyai nilai gizi tinggi dan mengandung zat-zat yang berkhasiat untuk meningkatkan kesehatan, mutunya tinggi (tidak sekedar enak tetapi mempunyai kriteria mutu yang baik). (3) Diproduksi dengan cara-cara 
yang tidak menurunkan mutu lingkungan. (5) Diproduksi dengan memperhatikan keselamatan dan kesejahteraan petani dan pekerja tani, (6) Konsumen menuntut adanya tracebility sehingga meyakinkan terpenuhinya syarat-syarat tersebut. Untuk mempertahankan produk hortikultura tetap dalam kondisi segar dan tidak rusak sampai ke tangan konsumen, memerlukan inovasi yang cukup tinggi. Manajemen rantai pasokan berperan dalam menjaga kondisi agar kualitas awal produk dapat dipertahankan dan masa hidup produk bisa diperpanjang (Fizzanty, 2012).

Agribusiness Development Centre (ADC) merupakan suatu organisasi hasil kerjasama antara Institut Pertanian Bogor (IPB) dan Taiwan International Cooperation and Development Fund (ICDF). Kerjasama ini mulai pada tahun 2007 dan berakhir pada tahun 2014, bertujuan agar melalui organisasi dapat dicapai produk hortikultura yang memenuhi syarat keinginan konsumen. ADC bekerjasama dengan petani dengan cara memberikan pelatihan dan pembinaan agar para petani memiliki pengetahuan,dan keterampilan, untuk menghasilkan suatu produk lebih bernilai. Penelitian dan penghitungan yang tepat juga mencakup jumlah lahan dan jumlah petani yang diperlukan sehinga hasil pertanian lebih baik dan dapat dipasarkan dengan harga yang baik, dan tidak merugikan petani. Keberhasilan mengembangkan produk hortikultura sebagian besar didasarkan pada efisiensi dan fleksibilitas dari sistem pemasaran, menghubungkan petani kecil untuk pedagang merupakan strategi penting untuk meningkatkan pendapatan masya- rakat pedesaan, mengurangi kemiskinan dan mencapai ketahanan pangan (Dayanandan, 2013).

ADC menerima subsidi dari Taiwan ICDF berupa benih, biaya operasional, sarana dan prasarana yang ada di ADC. Pada tahun 2014 mendatang ADC tidak akan menerima subsidi dari Taiwan. ADC harus mampu secara konsisten pada menjaga mutu produk, dan tetap sebagai organisasi yang mendukung petani hortikultura setempat. Diperlukan suatu perencanaan strategik pemasaran yang tepat agar ADC dapat bertahan dan menjalankan organisasi sesuai dengan tujuan didirikannya ADC.

\section{Perumusan Masalah}

Taiwan melalui ICDF memberikan subsidi berupa benih, biaya operasional sejumlah dana yang kemudian dikelola oleh ADC untuk membiayai operasional kegiatan usaha, sarana dan prasarana yang ada di ADC. Pada tahun 2014 subsidi berupa biaya operasional tersebut akan dihentikan, sehingga diperlukan suatu perencanaan strategik pemasaran agar ADC dapat terus melakukan kegiatan usaha dan tetap berpihak pada petani. Berdasarkan uraian di atas maka dirumuskan beberapa pertanyaan menyangkut perencanaan strategik pemasaran produk hortikultura di ADC IPB.

1. Bagaimana sistem produksi dan distribusi produk hortikultura yang dilakukan oleh ADC selama ini?

2. Bagaimana faktor internal (kekuatan dan kelemahan) dan eksternal (peluang dan ancaman) yang dihadapi ADC dalam upaya menghadapi lepas subsidi dari ICDF Taiwan? 
3. Bagaimana perencanaan strategik pemasaran yang tepat yang harus dilakukan oleh perusahaan untuk mewujudkan pola kemitraan agribisnis hortikultura?

\section{Tujuan Penelitian}

Penelitian ini dilakukan dengan tujuan sebagai berikut:

1. Mengidentifikasi sistem produksi dan distribusi produk hortikultura yang telah dilakukan oleh ADC.

2. Menganalisis fakor internal (kekuatan dan kelemahan) dan eksternal (peluang dan ancaman) yang dihadapi ADC dalam upaya menghadapi lepas subsidi dari ICDF Taiwan.

3. Memberikan rekomendasi tentang perencanaan strategik yang tepat bagi ADC.

\section{PENELITIAN TERDAHULU}

Penelitian terdahulu yang berhubungan dengan penelitian ini telah dilakukan oleh Saputra, et al (2009) melakukan penelitian dengan tujuan menganalisis strategi pengembangan ternak yang dilaksanakan di Provinsi Aceh, alat analisis yang digunakan dalam penelitian ini adalah Internal Factor Evaluation (IFE), External Factor Evaluation (EFE), Strength Weakness Opportunities Threat (SWOT), dan Quantitative Strategic Planning Matrix (QSPM).

Shojaei (2010), melakukan penelitian dengan tujuan pengembangan strategi yang tepat untuk perusahaan menufaktur, alat analisis yang digunakan pada penelitian ini adalah SWOT, QSPM, dan Multi Atributte Utility Theory (MAUT).
Ernies (2011) melakukan penelitian dengan tujuan merekomendasikan prioritas strategi yang dapat diterapkan untuk pengembangan teknologi dan inovasi usaha tanaman hias di PT. Saung Mirwan dengan alat analisis penelitian SWOT dan QSPM.

Hedy (2010) melakukan penelitian dengan tujuan menerapkan strategi pemasaran untuk meningkatkan potensi produk white cement. Affrillita 2013 mengadakan penelitian mengenai analisis SWOT dalam menentukan strategi pemasaran sepeda motor pada PT. Samekarindo Indah di Samarinda dengan alat analisis IFE dan EFE kemudian analisis SWOT. Kaitan penelitian ini dengan penelitian terdahulu adalah kesamaan dalam penggunaan alat analisis, namun waktu dan objek penelitian berbeda.

\section{METODE PENELITIAN}

\section{Lokasi dan Waktu}

Pengumpulan data penelitian telah dilakukan pada bulan Juli 2013 hingga Agustus 2013 di Agribusiness Development Center IPB. Penelitian dilakukan di ADC IPB karena merupakan pusat agribisnis yang bekerja sama dengan para petani untuk menyalurkan hasil kebun petani ke pasar modern.

\section{Jenis dan Sumber Data}

Data yang digunakan dalam penelitian ini adalah data primer dan data sekunder yang berkaitan dengan topik penelitian. Data primer diperoleh dari wawancara terstruktur dengan menggunakan kuesioner kepada para pakar sebagai responden. Data sekunder 
diperoleh dari berbagai sumber melalui studi pustaka, instansi dan kelembagaan lainnya serta literatur internet.

\section{Teknik Pengambilan Contoh}

Metode dan teknik pengambilan contoh yang dilakukan pada penelitian ini adalah metode studi kasus dengan teknik non probability sampling, yaitu teknik yang tidak memberikan peluang atau kesempatan sama bagi setiap anggota populasi. Responden ditentukan secara sengaja (purposive sampling), teknik penentuan sampel dengan pertimbangan tertentu (Sangaji dan Sopiah, 2010). Berdasarkan kriteria tersebut maka diperoleh 6 orang responden yang terdiri atas tiga orang pakar dan tiga orang pihak ADC. Responden-responden tersebut adalah Prof. Dr. Ir. Syafrida Manuwoto, Prof. Dr. Ir. Rhoedy Poerwanto, Dr. Ir. Anas D Susila, Ezipotia Rusli, Tisna Prasetyo, dan Faiqotul Himma. Nama dan jabatan para responden dapat dilihat pada tabel Data Responden (Tabel 1).

\section{Kerangka Operasional Penelitian}

Agribussiness Development Centre (ADC), membina dan mengupayakan agar para petani memiliki pengetahuan, keterampilan, dan modal untuk menghasilkan suatu produk yang lebih bernilai. Saat ini ADC menerima subsidi dari Taiwan ICDF, pada tahun 2014 ADC tidak akan menerima subsidi dari Taiwan. Persaingan antar organisasi kelompok tani serupa semakin kompetitif sehingga ADC memerlukan perencanaan strategik yang tepat untuk dapat konsisten sebagai organisasi yang mendukung para petani setempat meningkatkan penjualan produk hortikultura petani anggota.

Penelitian ini menggunakan alat analisis, Internal Factor Evaluation, External Factor Evaluation, SWOT, dan Quantitaitve Strategic Planning matrix. Langkah-langkah analisis tersebut untuk menyusun perencanaan strategik pemasaran produk hortikultura di ADC. Langkah pertama dari penelitian ini adalah dengan mengevaluasi Faktor internal dan eksternal (IFE dan EFE) yang berpengaruh terhadap perencanaan strategik produk hortikultura di ADC. Faktor-faktor yang termasuk kedalam kelompok kekuatan (strengths) dan kelemahan (weaknesses) dikelompokkan menjadi faktor internal. Faktor-faktor

Tabel 1. Data Responden

\begin{tabular}{lll}
\hline No & Nama & \multicolumn{1}{c}{ Jabatan } \\
\hline 1 & Prof. Dr. Ir. Syafrida Manuwoto & $\begin{array}{l}\text { Guru besar depertemen proteksi tanaman } \\
\text { IPB }\end{array}$ \\
2 & Prof. Dr. Ir. Roedhy Poerwanto & $\begin{array}{l}\text { Guru Besar departemen agronomi dan } \\
\text { hortikultura IPB }\end{array}$ \\
3 & Dr. Ir. Anas D Susila & Kepala University Farm IPB \\
4 & Ezipotia Rusli & Manajer ADC \\
5 & Tisna Prasetyo & Divisi Produksi ADC \\
6 & Faiqotul Himma & Divisi Pemasaran ADC \\
\hline
\end{tabular}




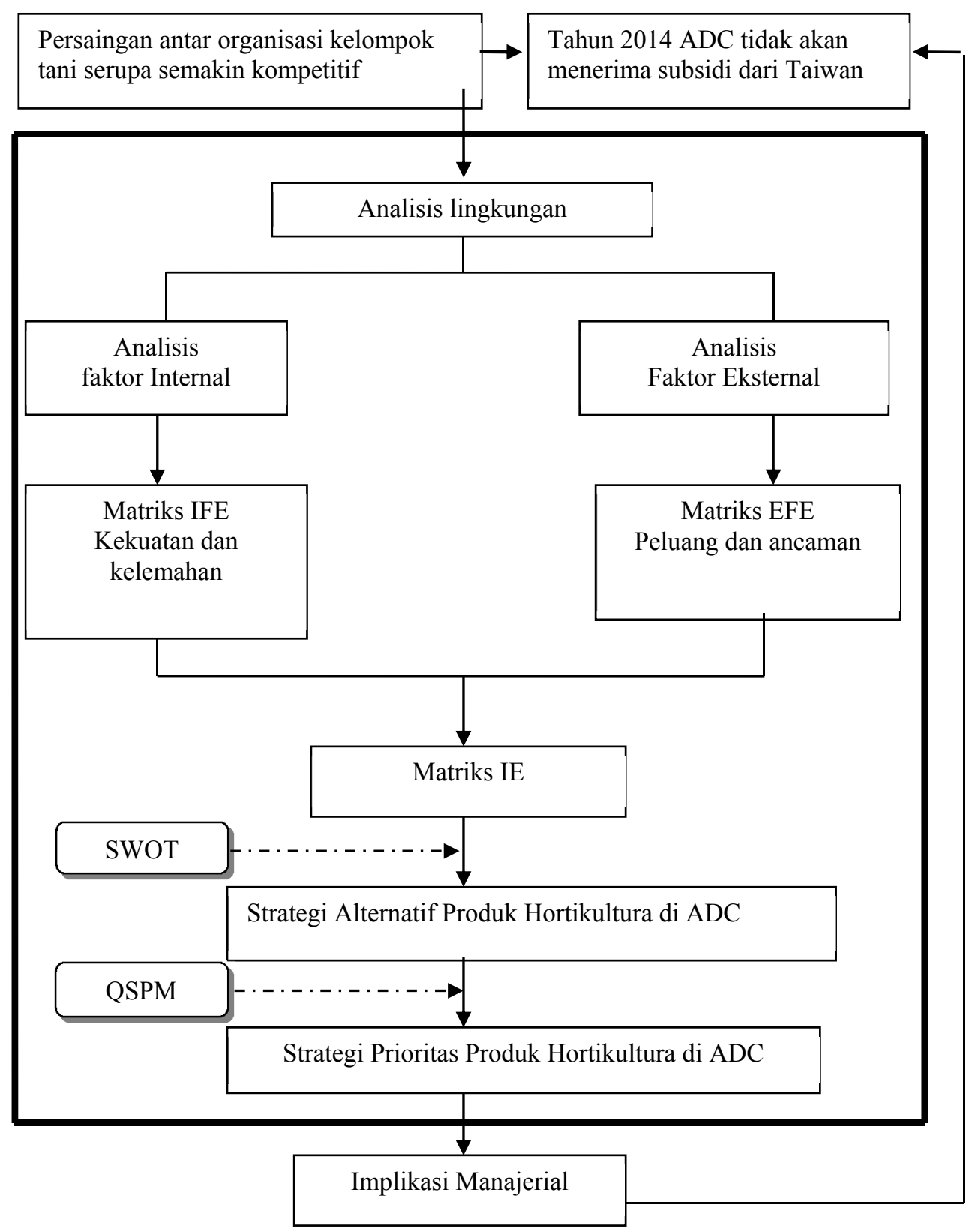

Gambar 1. Kerangka operasional penelitian

yang masuk dalam kelompok peluang (opportunities) dan ancaman (threats) dikelompokan dalam faktor eksternal. Identifikasi dan penggalian informasi alasan dan deskripsi masing-masing faktor dilakukan melalui wawancara menggunakan kuesioner terhadap para responden.

Setelah melakukan identifikasi faktor internal dan eksternal tersebut, 
kemudian dilakukan pembobotan dan rating factor internal dan eksternal. Pembobotan dan rating tersebut akan menghasilkan suatu nilai Internal Factor Evaluation (IFE) dan nilai External Factor Evaluation (EFE). Gabungan dari nilai IFE dan EFE, akan menunjukkan posisi ADC pada matriks IE (Internal Eksternal). Kemudian gambaran dari matriks IE tersebut menjadi acuan dalam menentuan strategi alternatif perencanaan strategik produk hortikultura melalui analisis matriks SWOT. Pemilihan prioritas strategik produk hortikultura di analisis melalui QSPM. Implementasi strategi yang diperoleh melalui analisa tersebut diserahkan kepada manajemen ADC karena batasan penelitian ini adalah hanya pada tahap menentukan strategi prioritas yang dapat dimplementasikan. Secara ringkas, kerangka pemikiran konseptual penelitian strategi bauran pemasaran produk hortikultura ADC dapat dilihat pada kerangka pemikiran konseptual (Gambar 1).

\section{HASIL DAN PEMBAHASAN}

\section{Sistem produksi dan distribusi ADC}

Produk-produk di ADC terbagi ke dalam tiga kelompok yaitu buah, sayur organik, dan sayur non organik. Kelompok buah hanya satu komoditi yaitu jambu kristal. Kelompok sayur organik terdiri atas 7 (tujuh) komoditi yaitu bayam merah, bayam hijau, kangkung, caisin, pakcoy, selada keriting, dan baby kaylan. Kelompok sayur non organik terdiri atas 11 (sebelas) komoditi yaitu asparagus, baby buncis, tomat ceri, oyong Taiwan, labu Taiwan, bunga kucai, kacang panjang merah, okra merah, pare putih, lobak merah, dan terong bulat.

Pada umumnya sistem produksi dan distribusi produk hortikultura, hanya dilakukan oleh petani, dan langsung di jual ke pasar atau melalui tengkulak. Sistem produksi dan distribusi seperti ini tidak memberikan keuntungan baik bagi petani, maupun bagi konsumen. Petani umumnya menanam suatu komoditi tanpa mengetahui jenis, mutu, dan jumlah produksi panen melimpah dan harga jual sangat rendah. Pada saat tidak musim panen produksi terbatas dan terjadi fenomena lonjak harga. Pada kedua situasi tersebut biasanya pedagang, pengumpul (tengkulak) dan pedagang besar (grosir) yang mendapat keuntungan besar

\section{Sistem Produksi ADC}

Petani adalah rantai paling penting dalam manajemen rantai pasokan produk hortikultura, petani membutuhkan berbagai informasi yang diperlukan dalam pengolahan lahan milik petani (Shalendra, 2013). Untuk menghasilkan suatu produk yang sesuai dengan keinginan konsumen baik jenis, jumlah dan mutunya ADC memiliki sistem produksi yang terdiri atas: kuota tanam, pengawasan oleh pembina, panen dan penanganan pasca panen, pengiriman ke ADC, grading, dan pengemasan. Cara seperti ini adalah penerapan dari sistem manajemen rantai pasokan, jumlah, jenis, kualitas, dan ketepatan waktu, dari suatu komoditi sesuai dengan keinginan konsumen.

Kuota tanam adalah jumlah permintaan terhadap salah satu jenis produk ADC. Selain kuota tanam yang menjadi 
perhatian divisi produksi adalah rotasi tanam. Rotasi tanam penting dilakukan untuk memutus siklus hama dan penyakit tanaman yang mungkin menyerang suatu jenis tanaman.

Pembinaan dan pengawasan dilakukan dengan cara, pembina melakukan pemeriksaan ke setiap lahan milik petani. Kunjungan ke lahan petani memberikan kesempatan kepada para petani untuk membicarakan masalah-masalah yang dihadapinya dalam kegiatan budidaya tanaman. Cara ini efektif dalam mengurangi gagal panen dan meningkatkan produktivitas hasil panen.

Panen, dan penanganan pasca panen menjadi bagian terpenting, panen pada saat belum waktunya atau sudah terlalu matang akan berpengaruh pada mutu produk hortikultura. Grading dan pengemasan adalah proses terakhir pada sistem produksi yang dilakukan di ADC. Pada tahap sayuran-sayuran yang dibawa oleh petani akan dipilih apakah sesuai atau tidak dengan keinginan konsumen. Tahap ini dilakukan agar seluruh produk yang sampai pada konsumen adalah produk dengan mutu terjamin.

\section{Sistem Distribusi ADC}

Sistem distribusi di ADC dilakukan oleh divisi pemasaran. Langkah-langkah yang dilakukan oleh divisi pemasaran ADC untuk mendapatkan jumlah produk yang diinginkan oleh konsumen antara lain: survei pasar, mendatangi pasar, kunjungan pihak supermarket, dan negosiasi.

Survei pasar adalah proses ketika divisi pemasaran ADC menentukan pasar yang sesuai dengan segementasi konsu- men ADC, dan berlokasi sejalur arah pengiriman barang $\mathrm{ADC}$ dan sesuai dengan pangsa pasar ADC. Berdasarkan hal tersebut maka terpilih Supermarket yang berada di wilayah Jabodetabek, dekat dengan lokasi ADC. ADC masih memiliki keterbatasan dalam armada pengantaran barang.

Mendatangi pasar adalah proses selanjutnya setelah menentukan pasar yaitu supermarket yang ada di Jabodetabek selanjutnya tim pemasaran menghubungi pihak manajemen Supermarket untuk membuat janji bertemu. Sampel produk, dan daftar harga disiapkan. Selanjutnya tim pemasaran melakukan presentasi mengenai produk yang dibawa, harga dan cara ADC memperoleh produk tersebut, bahwa ADC bekerjasama dengan para petani. Untuk lebih meyakinkan pihak supermarket, ADC mengundang pihak supermarket untuk datang langsung ke ADC.

Pihak supermarket dapat melihat langsung, dari mulai pembenihan yang dilakukan di green house hingga produk tersebut di kemas dan siap dikirim. Pihak supermarket melihat packing house dan dapat mengetahui bagaimana produkproduk hasil panen petani dipilih dan disortir, serta ditentukan grade. Setelah disortir produk tersebut ditimbang, kemudian dikemas. Pihak supermarket juga dapat melihat storage yang dimiliki oleh ADC. Storage menjaga agar produk hasil petani tetap segar dan tidak mengalami penurunan kualitas.

Proses selanjutnya adalah negosiasi, divisi pemasaran datang kembali ke supermarket yang dipilih. Pada tahap ini 
akan ditentukan harga, jenis dan jumlah barang yang diinginkan oleh konsumen. Ketetapan lain seperti kapan mulai dilakukan pengiriman, dan syarat dan ketentuan yang diajukan oleh masingmasing pihak juga dibicarakan pada tahap ini. Kemudian pengiriman barang mulai dilakukan.

\section{Analisis Faktor Internal ADC}

\section{Kekuatan}

Faktor internal terdiri atas kekuatan dan kelemahan yang dimiliki oleh ADC. Kekuatan yang dimiliki olah ADC adalah produk unik dan berkualitas, petani dan pembina handal, memiliki sertifikat produk organik, memiliki packing house dan storage, dan komitmen manajemen tinggi. ADC memiliki produk unggulan yang tidak diproduksi oleh perusahaan lain seperti jambu kristal, pare putih, dan baby buncis. Petani dan pembina ADC secara konsisten melakukan sistem cara penanaman dan panen yang telah disepakati sehingga hasil panen para petani seragam. Lahan pertanian di dalam kebun ADC ataupun lahan milik petani memiliki sertifikat produk organik. Kepemilikan sertifikat tersebut menunjukkan bahwa prosedur pelaksanaan yang dilakukan telah sesuai syarat dan ketentuan produk organik. Tidak menggunakan pupuk kimia, dan pestisida. Setiap hasil panen petani melalui proses grading dan pengemasan ADC memiliki packing house dan storage yang berbeda untuk produk organik dan non organik. Petani dan pembina berkomitmen untuk menghasilkan produk dengan kualiatas terbaik. Hal yang menjadi penting adalah kejujuran, petani yaitu tetap menjalankan prosedur pengolahan lahan kegiatan usaha tani, dan penanganan pasca panen sesuai yang telah disepakati walaupun tanpa pengawasan.

\section{Kelemahan}

Kelemahan yang dimiliki oleh ADC adalah produksi belum stabil, belum memiliki SIUP dan NPWP, kegiatan promosi masih kurang, dan letak lahan saling berjauhan tidak dalam satu

Tabel 2. Matriks IFE ADC

\begin{tabular}{clccc}
\hline No & \multicolumn{1}{c}{ Faktor Strategis Internal } & Bobot & Rating & Skor \\
\hline I. Kekuatan & & & \\
1 & Produk Unik dan Berkualitas & 0,122 & 4 & 0,486 \\
2 & Petani dan Pembina yang Handal & 0,123 & 4 & 0,490 \\
3 & Memiliki Sertifikat Produk Organik & 0,084 & 3 & 0,254 \\
4 & Memiliki Packing House dan Storage & 0.101 & 4 & 0,402 \\
5 & Komitmen Manajemen Tinggi & 0,136 & 4 & 0,545 \\
\hline II. Kelemahan & 0,123 & 1 & 0,123 \\
1 & Produksi Belum Stabil & 0,106 & 2 & 0,213 \\
2 & Belum Memiliki SIUP dan NPWP & 0,105 & 2 & 0,210 \\
3 & Kegiatan Promosi Masih Kurang & 0,101 & 1 & 0,101 \\
\hline & Letak Lahan Berjauhan & $\mathbf{1 , 0 0 0}$ & & $\mathbf{2 , 8 2}$ \\
\hline \multicolumn{1}{c}{ Total } & & & \\
\hline
\end{tabular}


Tabel 3. Matriks EFE ADC

\begin{tabular}{llccc}
\hline No & \multicolumn{1}{c}{ Faktor Strategis Eksternal } & Bobot & Rating & Skor \\
\hline I. Peluang & & & \\
1 & Pasar Dalam Negeri Besar & 0,105 & 3 & 0,315 \\
2 & Dukungan Pemerintah & 0,112 & 2 & 0,224 \\
3 & Perubahan Gaya Hidup Masyarakat & 0,125 & 3 & 0,375 \\
4 & Loyalitas Konsumen & 0,134 & 4 & 0,536 \\
5 & Citra Produk yang Baik & 0,141 & 4 & 0,564 \\
\hline II. Ancaman & & & \\
$1 \quad$ Keberadaan Usaha Sejenis & 0,104 & 3 & 0,312 \\
2 & Kondisi Iklim Cuaca yang Tidak Menentu & 0,144 & 3 & 0,432 \\
3 & Kondisi Ekonomi yang Tidak Stabil & 0,127 & 2 & 0,254 \\
\hline \multicolumn{2}{c}{ Total } & $\mathbf{1 , 0 0 0}$ & $\mathbf{3 , 0 1}$ \\
\hline
\end{tabular}

kawasan. Stok atau ketersediaan produk hortikultura belum stabil sesuai permintaan supermarket ADC belum dapat memenuhi permintaan tersebut. ADC kesulitan dalam memasarkan produknya karena beberapa supermarket mensyaratkan kepemilikan SIUP dan NPWP. Promosi merupakan aktivitas menawarkan produk atau jasa yang bertujuan menarik orang lain untuk membeli, menggunakan atau bahkan hanya melirik produk atau jasa yang ditawarkan, ADC belum melakukan promosi melalui media massa. Letak lahan yang berjauhan membuat proses pengantaran hasil panen ke ADC memakan waktu lebih lama dan dapat menyebabkan penurunan mutu sayur segar. Penghitungan bobot dan rating pada faktor-faktor internal menunjukkan nilai Internal Factor Evaluation untuk ADC adalah 2,82.

\section{Analisis Faktor Eksternal ADC}

\section{Peluang}

Faktor eksternal terdiri atas peluang dan ancaman yang dihadapi oleh ADC.
Peluang yang dihadapi oleh ADC adalah pasar dalam yang negeri besar, dukungan pemerintah, loyalitas konsumen, dan citra produk hortikultura organik semakin baik dimasyarakat. Supermarket dan pasar modern banyak didirikan terutama di daerah Jabodetabek, pasar modern ini masih banyak yang belum bekerjasama dengan ADC. Pemerintah mengeluarkan kebijakan "Go Organic 2010" yang mendukung pengembangan pertanian organik. Citra produk hortikultura organik sebagai produk yang lebih baik dari produk non organik, membuat masyarakat semakin sadar untuk menerapkan pola hidup sehat, dan mengkonsumsi sayuran organik ke dalam menu makan sehari-hari. ADC mendapat dukungan dari IPB dan Taiwan ICDF, konsumen akan langsung menyadari mutu yang yang ada pada produk ADC.

\section{Ancaman}

Sedangkan ancaman yang dihadapi oleh ADC adalah keberadaan usaha sejenis, kondidi iklim cuaca yang tidak 
menentu, dan kondisi ekonomi yang tidak stabil. Semakin ketatnya persaingan antar perusahaan sejenis dan semakin kritisnya konsumen dalam memilih produk, merupakan suatu ancaman setiap produsen atau perusahaan. Iklim cuaca yang tidak menentu akan berpengaruh pada hasil panen, dan cenderung mengakibatkan gagal panen. Kondisi ekonomi yang tidak stabil berpengaruh pada kenaikan harga barang, dan akhirnya meningkatkan biaya produksi. Penghitungan bobot dan rating pada faktor-faktor eksternal menunjukkan nilai external factor evaluation untuk ADC adalah 3,01. Untuk lebih jelas hasil penghitungan bobot dan rating faktor internal dapat dilihat pada matriks IFE Tabel 2 dan hasil penghitungan bobot dan rating faktor eksternal dapat dilihat pada Matriks EFE Tabel 3.

Matriks IFE (Tabel 2) menjelaskan bahwa faktor kekuatan utama yang dimiliki oleh ADC adalah produk unik dan berkualitas dengan bobot 0,122 nilai ini juga mengartikan bahwa produk unik dan berkualitas adalah faktor kekuatan yang paling berpengaruh untuk perencanaan strategik produk hortikultura di ADC sedangkan faktor kelemahan utama yang dimiliki oleh ADC adalah produksi belum stabil dengan bobot 0,123 . Nilai ini menunjukkan bahwa produksi belum stabil adalah kelemahan utama dari ADC.

Matriks EFE (Tabel 3) menjelaskan bahwa faktor peluang utama ADC adalah citra produk yang baik sedangkan yang menjadi ancaman utama ADC adalah kondisi iklim cuaca yang tidak menentu.

\section{Analisis Matriks Internal External (IE)}

Nilai IFE ADC adalah 2,82, dan nilai EFE ADC adalah 3,01 berdasarkan nilai tersebut posisi ADC berada pada kuadran II Matriks Internal dan Eksternal (IE). Nilai tersebut menunjukan bahwa pada saat ini faktor eksternal ADC yaitu

\section{SKOR BOBOT TOTAL IFE}

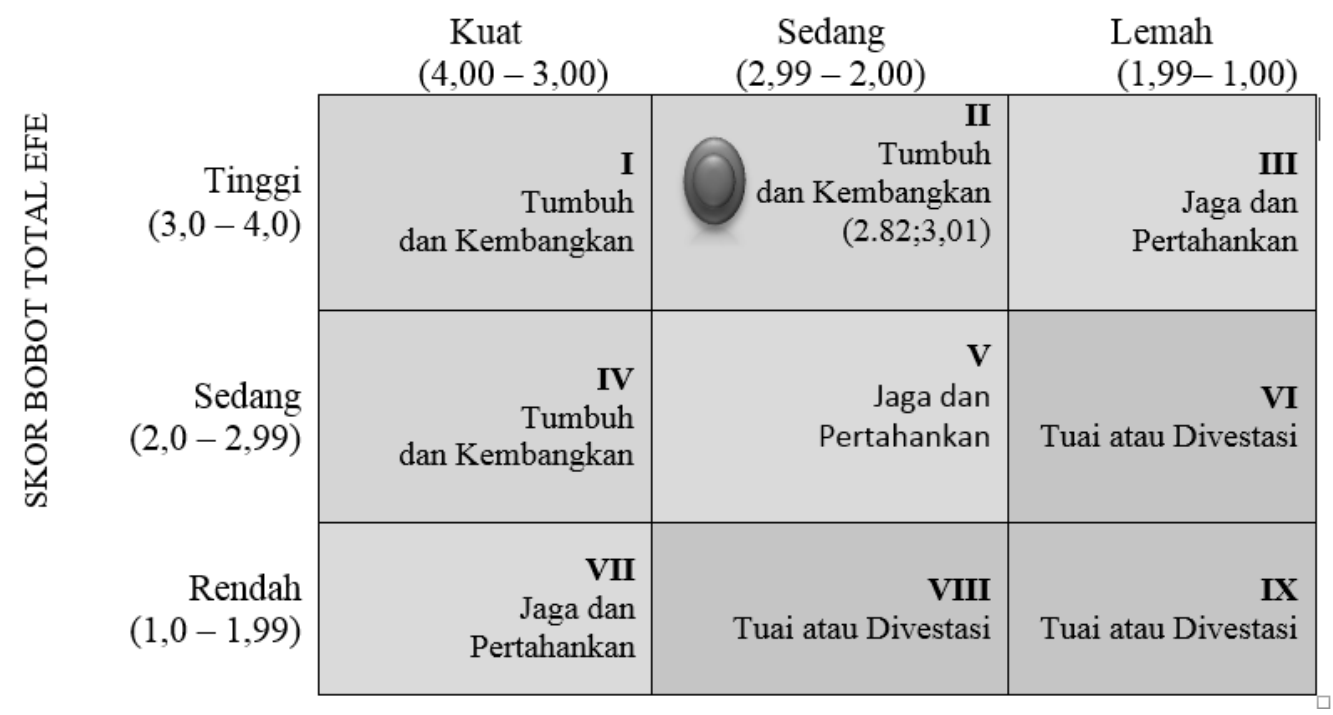

Gambar 2. Matriks IE ADC 
peluang dan ancaman lebih kuat dari faktor internal ADC yaitu kekuatan dan kelemahan Letak ADC pada kuadran II dapat dilihat pada Matriks IE (Gambar 2). Berdasarkan posisi tersebut strategi yang disarankan adalah strategi integrasi dan starategi intensif. Strategi integrasi ke depan ADC bekerjasama dengan supermarket-supermarket yang berada di wilayah Jabodetabek agar produk hortikultura ADC dapat diperoleh dengan mudah oleh konsumen. Strategi integrasi kebelakang ADC memanfaatkan petani dan pembina yang handal untuk terus meningkatkan produksi produk hortikultura. Strategi Intensif, memanfaatkan pasar yang sudah ada (existing) dengan produk yang sudah ada, pengembangan pasar baru dengan memanfaatkan produk yang sudah ada, pengembangan produk memanfaatkan pasar yang ada dengan pengembangan produk baru didasarkan pada penetrasi pasar lama dengan melakukan modifikasi atau mengembangkan produk baru yang kaitannya jelas dengan lini produk yang ada.

\section{Analisis Matris SWOT (Strength Weakness Opportunity Threats)}

Analisis matriks SWOT merupakan kelanjutan dari analisis matriks IFE dan EFE dengan mencocokkan faktor-faktor internal (kekuatan dan kelemahan) dengan faktor-faktor eksternal (peluang dan ancaman) yang berpengaruh dalam perencanaan strategik pemasaran produk hortikultura di ADC IPB. Hasil formulasi dikelompokkan menjadi empat kelompok formulasi strategi yang terdiri atas strategi Kekuatan - Peluang (S-O), strategi Kekuatan - Ancaman (S-T), strategi Kelemahan - Peluang $(\mathrm{W}-\mathrm{O})$, strategi Kelemahan - Ancaman $(\mathrm{W}-\mathrm{T})$. Berdasarkan analisis matriks SWOT terdapat 5 alternatif strategi yang dapat dilakukan.

Strategi S-O; 1. Memperluas pasar di Jabodetabek. Masyarakat saat ini semakin peduli untuk mengkonsumsi sayur dan buah segar, selain itu mutu dari sayur dan buah segar tersebut juga menjadi pertimbangan. Masyarakat mencari buah dan sayur segar di pasar-pasar modern seperti supermarket. 2. Menambah produksi produk organik. Seiring dengan munculnya gerakkan Go Organic 2010, masyarakat semakin banyak yang peduli, pada asupan makanan dan zat-zat yang ada pada makanan yang dikonsumsi.

Strategi W-O meningkatkan kegiatan promosi. Kegiatan promosi yang dilakukan tidak hanya melalui media massa tetapi dapat dilakukan dengan mengajak masyarakat sekitar yaitu dosen dan mahasiswa IPB dengan gerakan melakukan pola hidup sehat. Strategi S-T memperluas saluran distribusi dan pemasaran baru ADC dapat menyalurkan produk tidak hanya pada supermarket namun bisa memasuki perkantoran, restoran dan rumah sakit. Strategi W-T bekerjasama dengan lembaga penelitian dan pengembangan. Lembaga penenlitian dan pengembangan yang dimaksud adalah penelitian dan pengembangan mengenai bibit unggul, seperti bibit yang yang lebih tahan terhadap perubahan iklim dan cuaca. Perumusan strategi alternatif dapat dilihat pada Matriks SWOT ADC (Gambar 3). 


\begin{tabular}{|c|c|c|}
\hline Faktor Eksternal & $\begin{array}{l}\text { STRENGTHS (S) } \\
\text { 1. Produk Unik dan Berkualitas } \\
\text { 2. Petani dan Pembina yang } \\
\text { Handal } \\
\text { 3. Memiliki Sertifikat Produk } \\
\text { Organik } \\
\text { 4. Memiliki Packing House dan } \\
\text { Storage } \\
\text { 5. Komitmen Manajemen Tinggi }\end{array}$ & $\begin{array}{l}\text { WEAKNESSESS (W) } \\
\text { 1. Produksi Belum Stabil } \\
\text { 2. Belum Memiliki SIUP dan } \\
\text { NPWP } \\
\text { 3. Kegiatan Promosi Masih } \\
\text { Kurang } \\
\text { 4. Letak Lahan Berjauhan }\end{array}$ \\
\hline $\begin{array}{l}\text { OPPORTUNITIES (O) } \\
\text { 1. Pasar Dalam Negeri } \\
\text { Besar } \\
\text { 2. Dukungan Pemerintah } \\
\text { 3. Perubahan Gaya Hidup } \\
\text { Masyarakat } \\
\text { 4. Loyalitas Konsumen } \\
\text { 5. Citra Produk yang Baik }\end{array}$ & $\begin{array}{l}\text { Strategi S-O } \\
\text { (mengelola kekuatan untuk } \\
\text { memanfaatkan peluang) } \\
\text { 1. } \begin{array}{l}\text { Memperluas pasar di } \\
\text { jabodetabek }\end{array} \\
\text { (S1,O1,O3) } \\
\text { 2. } \begin{array}{l}\text { Menambah produksi produk } \\
\text { organik } \\
(\mathrm{S} 3, \mathrm{~S} 4, \mathrm{O} 4)\end{array}\end{array}$ & $\begin{array}{l}\quad \text { Strategi W-O } \\
\text { (mengatasi kelemahan untuk } \\
\quad \text { memanfaatkan peluang) } \\
\text { Meningkatkan kegiatan promosi } \\
(\mathrm{W} 2, \mathrm{~W} 3, \mathrm{O} 2, \mathrm{O} 5)\end{array}$ \\
\hline \begin{tabular}{ll}
\multicolumn{1}{c}{ THREATS(T) } \\
1. \\
Keberadaan Usaha \\
Sejenis \\
2. Kondisi Iklim Cuaca \\
yang Tidak Menentu \\
3. Kondisi Ekonomi yang \\
Tidak Stabil
\end{tabular} & $\begin{array}{l}\text { Strategi S-T } \\
\text { (mengelola kekuatan untuk } \\
\text { mengantisipasi ancaman) } \\
\text { Memperluas Saluran distribusi } \\
\text { dan pemasaran baru } \\
(\mathrm{S} 2, \mathrm{~S} 5, \mathrm{~T} 1)\end{array}$ & $\begin{array}{c}\text { Strategi W-T } \\
\text { (mengatasi kelemahan untuk } \\
\text { mengantisipasi ancaman) } \\
\text { Bekerjasama dengan lembaga } \\
\text { penelitian }(\mathrm{W}, 1, \mathrm{~W} 4, \mathrm{~T} 2, \mathrm{~T} 3)\end{array}$ \\
\hline
\end{tabular}

\section{Gambar 3. Matriks SWOT ADC}

Analisis Quantitative Strategic Plannning Matrix (QSPM)

Tahap keputusan merupakan tahap ketiga dalam perumusan strategi yaitu menentukan daya tarik relatif dari berbagai tindakan alternatif strategi yang dihasilkan. Pada tahap ini strategi alternatif yang berhasil dibentuk pada matriks SWOT akan ditentukan prioritas strategi-strategi tersebut. Berdasarkan pengolahan data dengan QSPM diperoleh strategi terbaik berdasarkan daya tarik relatif dari berbagai strategi yang dihasilkan. Total nilai daya tarik Sum Total Attractive Score (STAS) tertinggi terdapat pada strategi S-O (1) yaitu memperluas pasar di Jabodetabek, dengan nilai 6,497. Nilai STAS tertinggi kedua adalah strategi S-O (2) yaitu meningkatkan produksi produk organik dengan nilai STAS 6,304. Berturut-turut berdasarkan nilai STAS adalah strategi W-T yaitu melakukan kerjasama dengan lembaga penelitian dengan nilai 6,272. Peringkat keempat adalah strategi dengan nilai 6,110 yaitu strategi $\mathrm{W}-\mathrm{O}$ yaitu meningkatkan kegiatan promosi. Peringkat kelima dengan nilai STAS 6,022 adalah S-T menambah saluran distribusi dan pemasaran baru.

\section{SIMPULAN DAN SARAN}

\section{Simpulan}

Sistem produksi dan distribusi yang dilakukan di ADC melibatkan banyak pihak dari mulai penanaman suatu 
komoditi, hingga sampai ke tangan konsumen. Semua pihak yang terkait pada sistem produksi dan distribusi berkomitmen untuk memberikan produk dengan mutu terbaik sesuai keinginan konsumen. Cara seperti ini sesuai dengan konsep Manajemen Rantai Pasokan, suatu produk untuk sampai ke tangan konsumen melalui beberapa pihak agar tercapai jenis, kualitas, kuantitas dan kontinuitas suatu produk.

Analisis faktor internal menunjukkan bahwa faktor kekuatan komitmen manajemen yang tinggi merupakan faktor kekutan dengan skor tertinggi. Sedangkan faktor kelemahan dengan skor terendah adalah letak lahan berjauhan. Analisis faktor eksternal menunjukkan bahwa faktor peluang citra produk baik memiliki skor tertinggi. Faktor ancaman kondisi iklim cuaca tidak menentu memiliki skor tertinggi.

Hasil analisis SWOT menunjukkan 5 (Lima) alternatif strategi yaitu: memperluas pasar di Jabodetabek, menambah produksi produk organik, meningkatkan kegiatan promosi, menambah saluran distribusi dan pemasaran baru, bekerjasama dengan lembaga penelitian. Analisis QSPM menunjukkan urutan prioritas strategi 1) memperluas pasar di Jabodetabek 2) meningkatkan produksi produk organik, 3) bekerjasama dengan lembaga penelitian, 4) meningkatkan kegiatan promosi, 5) menambah saluran distribusi dan pemasaran baru.

\section{Saran}

Terkait dengan strategi prioritas 1 memperluas pasar di Jabodetabek, kegiatan yang dapat dilakukan oleh ADC adalah dengan terus melakukan survey pasar, dan mendatangi pasar di Jabodetabek yang sesuai dengan segementasi konsumen ADC yaitu supermarket yang belum bekerjasama dengan ADC. Strategi meningkatkan produksi produk organik melibatkan petani-petani organik anggota ADC. Kegiatan yang dapat dilakukan adalah menambah petanipetani baru, dan memperketat pembinaan langsung ke lahan lahan milik petani.

Strategi yang ketiga yaitu bekerjasama dengan lembaga penelitian. Masalah utama yang dihadapi ADC adalah perubahan iklim cuaca yang seringkali menyebabkan gagal panen sehingga produksi tidak stabil. Lembaga penelitinan dan pengembangan dapat memberikan pengetahuan baru mengenai bibit unggulan suatu produk hortikultura yang lebih tahan terhadap perubahan cuaca. Kerjasama dengan lembaga penelitian dan pengembangan juga diperlukan untuk mengetahui selera konsumen, mengenai produk-produk ADC.

Strategi yang keempat adalah meningkatkan kegiatan promosi produk. Kegiatan dapat berupa ajakan untuk memulai konsumsi makanan sehat yaitu sayur dan buah. Selain mengajak untuk konsumsi sayur dan buah melalui kegiatan ini ADC dapat menunjukkan cara memilih sayur segar, dan bagaimana cara memperolehnya.

Strategi terakhir adalah strategi menambah saluran distribusi dan pemasaran baru. Kegiatan yang dapat dilakukan adalah dengan bersosialisasi mengenai ADC pada rumah sakit atau restoran. 


\section{DAFTAR PUSTAKA}

Afrillita N. 2013. Analisis SWOT dalam Menentukan Strategi Pemasaran Sepeda Motor pada PT. Samekarindo Indah di Samarinda. E-Journal Administrasi Bisnis Vol 1.1 hal 56-70

Badan Pusat Statistik. 2006. Tingkat Pendidikan Petani Hortikultura Indonesia

Dayanandan. 2013. Food Security Through Farmer: Market Linkage Hortikultural Products. International Journal of Logistic and Supply Chain Management Persfective Vol 2/2 pp27-39

Ernies.2011. Strategi Pengembangan Teknologi dan Inovasi Usaha Tanaman Hias di PT. Saung Mirwan [Tesis]. Bogor(ID): Program Studi Manajemen Bisnis Institut Pertanian Bogor

Fizzanty T. 2012. Pengelolaan Logistik dalam Rantai Pasok Produk Pangan Segar di Indonesia. Jurnal Penelitian Pos dan Informatika vol 2/1 hal 17-33

Hedy M. 2010. Penerapan Analisis SWOT dalam Meningkatkan Potensi Produk pada PT. Indocement Tunggal Prakarsa TBK. Jurnal Manajemen UIKA. Volume 1. Nomor 1. Program Pascasarjana UIKA. Bogor

Poerwanto R. 2008. Membangun Pertanian Masa Depan : Meraih Keunggulan Pertanian Indonesia, p. 79-84. In. Kusumastanto T, U Sumarwan, R Poerwanto, W Manalu, J Haluan, I Rahayu, C Kusmana, B I Setiawan, dan Y Koesmaryono (Eds.) Pemikiran
Guru Besar Institut Pertanian Bogor : Persfektif Ilmu-ilmu Pertanian dalam Pembangunan Nasional. Penebar Swadaya dan IPB Press

Pusat Kajian Hortikultura Tropika. 2013. Konsumsi Perkapita Hortikultura

Sangaji E M, Sopiah. 2010. Metodologi Penelitian Pendekatan Praktis dalam Penelitian. Yogyakarta: Penerbit Andi

Saputra H, Daryanto A, Hendrawan D S. 2009. Strategi Pengembangan Ternak Sapi Potong Berwawasan Agribisnis di Aceh. Jurnal Manajemen dan Agribisnis. Volume nomer 6. Program Magister dan Bisnis IPB

Shalendra K C. 2013. User Centric ICT Model for Suply Chain of Horticultural Crops in India. Agricultural Economics Research Review Vol 26.1. pp 91-100

Shojaei M R. 2010. Strategic Planning For a Food Industry Equipment Manufacturing Factory, Using SWOT Analysis, QSPM, and MAUT Models. Asian Journal of Management Research

Sumantri C T. 2010. Strategi Kemitraan Agribisnis Stroberi di Asosiasi Agribisnis dan Wisata (ASGITA) Kecamatan Rancabali kabupaten Bandung Jawa Barat [Tesis]. Bogor (ID): Program Studi Manajemen Bisnis Institut Pertanian Bogor 